\title{
Sonnat-šekan. Tehrān, Țūs, 1378/1999, 167 p. [Le briseur de tradition, recueil de contes du Khorassan 1]
}

\section{OpenEdition}

\section{Journals}

Édition électronique

URL : http://journals.openedition.org/abstractairanica/35953

DOI : 10.4000/abstractairanica.35953

ISSN : 1961-960X

Éditeur :

CNRS (UMR 7528 Mondes iraniens et indiens), Éditions de l'IFRI

Édition imprimée

Date de publication : 15 mai 2002

ISSN : 0240-8910

Référence électronique

«Sonnat-šekan. Tehrān, Tūs, 1378/1999, 167 p. [Le briseur de tradition, recueil de contes du Khorassan 1] », Abstracta Iranica [En ligne], Volume 23 | 2002, document 251, mis en ligne le 08 février 2010, consulté le 25 septembre 2020. URL : http://journals.openedition.org/abstractairanica/35953 ; DOI : https://doi.org/10.4000/abstractairanica.35953

Ce document a été généré automatiquement le 25 septembre 2020

Tous droits réservés 
Sonnat-šekan. Tehrān, Ṭūs, 1378/1999, 167 p. [Le briseur de tradition, recueil de contes du Khorassan 1]

INDEX

Thèmes : 11.1.0. Généralités 